\title{
ANALISA DAN PERANCANGAN SISTEM PENJUALAN BARANG BERBASIS WEB PADA PT. ASIA TIARA
}

\author{
${ }^{1}$ Christian Sujana, 2Darmansyah \\ Email : christiansjn91@gmail.com, trackdrs@yahoo.com
}

\begin{abstract}
Abstrak
Perkembangan teknologi informasi telah mempermudah kegiatan manusia dalam kehidupan seharihari. Salah satu teknologi yang sangat membantu dalam kegiatan manusia sehari-hari adalah teknologi internet, yang sering digunakan untuk berbagai kegiatan seperti berkomunikasi, mencari informasi atau untuk kegiatan jual beli juga kegiatan lainnya. PT. Asia Tiara dalam kegiatan transaksi penjualannya menggunakan sarana surat elektronik dan telepon untuk berkomunikasi dengan pelanggan, adapun data-data transaksi yang digunakan hanya disimpan dalam bentuk dokumen fisik. Tujuan dari penelitian ini adalah untuk menganalisis dan merancang sebuah sistem penjualan berbasis web untuk mempermudah kegiatan perusahaan dalam transaksi penjualan juga pengolahan data-data transaksinya. Metode pengembangan yang digunakan dalam pengembangan sistem penjualan berbasis web ini adalah metode Waterfall yang terdiri dari lima tahapan, yaitu analisis dan definisi kebutuhan, perancangan sistem dan perangkat lunak, implementasi dan pengujian unit, integrasi dan pengujian sistem, operasi dan pemeliharaan. Sistem ini dibuat menggunakan bahasa pemrograman PHP, dan untuk pemodelan dari rancangan sistem menggunakan UML (Unified Modelling Language). Hasil akhir dari penelitian ini adalah dihasilkannya sebuah sistem penjualan barang berbasis web yang dapat digunakan sebagai sarana transaksi penjualan barang dan juga melakukan pengolahan data-data transaksi.
\end{abstract}

Kata Kunci :Penjualan, Website

\begin{abstract}
The development of information technology has facilitated human activities in everyday life. One of the technologies that is very helpful in human activities everyday is internet technology, which is often used for various activities such as communicating, seeking information or for buying and selling activities as well as other activities. PT. Asia Tiara in its sales transaction using the means of electronic mail and telephone to communicate with customers, while the transaction data used is only stored in the form of physical documents. The purpose of this study is to analyze and design a web-based sales system to facilitate the company's activities in sales transactions as well as in processing data transactions. The development method used in the development of web-based sales system is Waterfall method that consists of five stages, namely requirements analysis and definition, system and software design, implementation and unit testing, integration and system testing, operation and maintenance.This system is created using PHP programming language, and the modelling of the system design using UML (Unified Modelling Language). The end result of this research is a web-based goods sales system that can be used as a means of goods sales transactions and transaction data processing.
\end{abstract}

Keywords: Sales, Website

Jurnal Interkom Vol. 12 No. 4 - Januari 2018 


\section{PENDAHULUAN}

\section{Latar Belakang}

Teknologi dalam dekade belakangan telah berkembang begitu pesat terutama di bidang teknologi informasi. Suatu hal yang tidak terbantahkan lagi bahwa orang-orang yang hidup di era teknologi ini, harus mengikuti perkembangan. Baik di tempat kerja ataupun dalam melakukan kegiatan sehari-hari sudah sangat mengandalkan teknologi-teknologi yang dapat mempermudah, mempercepat penyelesaian kegiatan-kegiatan yang dikerjakan.

Salah satu teknologi yang sangat membantu kegiatan manusia baik dalam pekerjaan ataupun kegiatan sehari-hari adalah internet. Internet, suatu teknologi yang sudah tidak asing lagi di era teknologi seperti sekarang. Internet juga bisa dikatakan sebagai suatu teknologi yang memiliki begitu banyak fungsi seperti untuk mencari informasi, untuk menjalin komunikasi dan hal lainnya. Penggunaan internet sudah menjadi alat persaingan antar perusahaan yang satu dengan lainnya. Untuk menghadapi kemajuan teknologi dan persaingan bisnis perusahaan-perusahaan harus siap dan memiliki kemampuan beradaptasi terhadap perkembangan zaman sehingga mampu bersaing dengan para kompetitor.

Perkembangan yang terjadi dalam teknologi internet, satu fenomena yang paling menarik dalam kemajuan teknologi yang terjadi sekarang. Diawali dengan munculnya electronic commerce (e-commerce) sebagai salah satu hasil dari perkembangan teknologi internet. $E$ commerce telah mengubah hampir semua fungsi dalam bisnis area dan setiap kegiatannya, mulai dari transaksi jual beli sampai periklanan. $E$ commerce telah memudahkan konsumen dalam melakukan kegiatan-kegiatan transaksi jual beli.

PT. Asia Tiara sebuah perusahaan perseroan terbatas yang bergerak di bidang perdagangan, khususnya barang mekanikal dan eletrikal. Kegiatan penjualan pada saat ini masih dilakukan secara konvensional, yaitu penawaran harga dilakukan melalui telepon atau pesan elektronik. Data transaksi penjualan dan pembelian, saat ini belum tersimpan secara digital, semua dokumen hasil transaksi penjualan dan pembelian disimpan dalam bentuk dokumen fisik saja. Hal ini membuat pencarian data transaksi penjualan dan pembelian menjadi terhambat karena data tertumpuk dalam jumlah yang banyak.

Perancangan sebuah website yang nantinya akan menjadi sarana untuk melakukan pemrosesan transaksi penjualan dan pembelian, juga menyediakan fitur untuk memesan barang secara langsung tentunya akan membantu perusahaan dalam proses penjualan barang. Penggunaan sebuah basis data untuk menyimpan semua data-data transaksi yang digunakan membuat kontrol terhadap data menjadi lebih baik. Pembuatan sebuah website juga akan memperluas jangkauan area pemasaran perusahaan. Berdasarkan hal tersebut, penulis tertarik melakukan penelitian dengan judul "Analisis dan Perancangan Sistem Penjualan Barang Berbasis Web Pada PT. Asia Tiara".

\section{TINJAUAN PUSTAKA}

\section{Definisi Sistem}

Definisi sistem menurut Subhan (2012 : 8), "suatu sistem dapat diartikan sebagai suatu kumpulan atau himpunan dari unsur, komponen, atau variable-variabel yang terorganisasi, saling berinteraksi, saling tergantung satu sama lain dan terpadu. Sistem juga merupakan kumpulan elemen-elemen saling terkait dan bekerja sama untuk memproses masukan (input) yang ditujukan kepada system tersebut dan mengolah masukan tersebut sampai menghasilkan keluaran (output) yang diinginkan."

\section{Definisi Penjualan}

Definisi penjualan menurut Puspitawati dan Anggadini (2011:165), "penjualan merupakan aktivitas memperjualbelikan barang dan jasa kepada konsumen."

Secara umum ada dua jenis penjualan, yaitu :

1. Penjualan Tunai

Definisi penjualan tunai menurut Mulyadi (2013:455), "penjualan tunai dilaksanakan oleh perusahaan dengan cara mewajibkan pembeli melakukan pembayaran harga barang terlebih dahulu sebelum barang 
diserahkan oleh perusahaan kepada pembeli."

Sedangkan menurut Puspitawati dan Anggadini (2011:167), "penjualan tunai merupakan penjualan yang dilakukan dengan cara menerima uang tunai/cash pada saat barang diserahkan kepada pembeli."

2. Penjualan Kredit

Definisi penjualan kredit menurut Mulyadi (2013:201), “penjualan kredit dilaksanakan oleh perusahaan dengan cara mengirimkan barang sesuai dengan order yang diterima dari pembeli dan untuk jangka waktu tertentu perusahaan mempunyai tagihan kepada pembeli tersebut."

\section{E-Commerce}

Definisi e-commerce menurut Wong (2013:33), "pembelian, penjualan dan pemasaran barang serta jasa melalui sistem elektronik. Seperti televisi, radio dan jaringan komputer atau internet.

\subsection{Definisi Website}

Definisi website menurut Arief (2011:8), "website adalah kumpulan dari halaman web yang sudah dipublikasikan di jaringan internet dan memiliki domain/URL (Uniform Resource Locator) yang dapat diakses semua pengguna internet dengan cara mengetikkan alamatnya."

\subsection{Definisi PHP}

Definisi PHP menurut Saputra, Subagio dan Saluky (2012:2), "PHP merupakan suatu bahasa pemrograman yang difungsikan untuk membangun suatu website dinamis. PHP menyatu dengan kode HTML, maksudnya adalah beda kondisi, HTML digunakan sebagai pembangun atau pondasi dari kerangka layout web sedangkan PHP difungsikan sebagai prosesnya."

\subsection{Definisi CSS}

Menurut Saputra, Subagio dan Saluky (2012:6), "CSS atau Cascading Style Sheet merupakan suatu bahasa pemrograman web yang digunakan untuk mengendalikan dan membangun berbagai komponen dalam web sehingga tampilan web akan lebih rapi, terstruktur, dan seragam."

\subsection{Definisi Javascript}

Menurut Kustiyahningsih dan Anamisa (2011:65), "JavaScript adalah bahasa yang berbentuk kumpulan skrip berjalan pada suatu dokumen HTML. Bahasa ini adalah bahasa pemrograman untuk memberikan kemampuan tambahan terhadap bahasa HTML dengan mengizinkan pengeksekusian perintah-perintah di sisi user artinya di sisi browser bukan di sisi server web."

\section{Definisi Database}

Menurut Connolly dan Begg (2010:65), "database adalah kumpulan data yang terhubung secara logis beserta deskipsinya, dirancang untuk memenuhi kebutuhan informasi di dalam sebuah organisasi. Basis Data adalah sebuah penyimpanan data yang besar yang bisa digunakan oleh banyak pengguna dan departemen. Semua data terintegrasi dengan jumlah duplikasi yang minimum. Basis Data tidak lagi dipegang oleh satu departemen, tetapi dibagikan ke seluruh departemen pada perusahaan. Basis Data itu sendiri tidak hanya memegang data operasional organisasi tetapi juga penggambaran dari data tersebut."

\section{Definisi XAMPP}

Menurut Arief (2011:44), "XAMPP merupakan aplikasi yang mengintegrasikan beberapa aplikasi utama web di dalamnya. Dalam XAMPP terdapat instalasi modul PHP, MySQL, web server Apache."

\section{Definisi MySQL}

Menurut Arief (2011:151), "MySQL adalah salah satu jenis database server yang sangat terkenal dan banyak digunakan untuk membangun aplikasi web yang menggunakan database sebagai sumber dan pengelolaan datanya."

\section{Definisi Sublime Text}

Menurut Haughee (2013:3), "sublime text adalah aplikasi editor untuk kode dan teks yang dapat berjalan di berbagai platform operating 
system dengan menggunakan teknologi Phyton API. Terciptanya aplikasi ini terinspirasi dari aplikasi Vim. Aplikasi ini sangatlah fleksibel dan powerfull. Fungsionalitas dari aplikasi ini dapat dikembangkan dengan menggunakan sublime-packages. Sublime Text bukanlah aplikasi open source, yang artinya aplikasi ini membutuhkan lisensi (license) yang harus dibeli. Akan tetapi beberapa fitur pengembangan fungsionalitas (packages) dari aplikasi ini merupakan hasil dari temuan dan mendapat dukungan penuh dari komunitas serta memiliki linsensi (license) aplikasi gratis."

\section{UML (Unified Modelling Language)}

Menurut Nugroho (2010:6), "UML adalah bahasa pemodelan untuk system atau perangkat lunak yang berparadigma (berorientasi objek)". Sedangkan menurut Widodo dan Herlawati (2011:6), "UML adalah bahasa pemodelan standar yang memiliki sintak dan semantik."

\section{METODOLOGI PENELITIAN}

Adapun metode penelitian yang digunakan dalam penelitian ini adalah menggunakan metode PIECES, yang bertujuan untuk mendapatkan gambaran yang jelas tentang pokok-pokok permasalahan dengan menganalisis sistem dalam beberapa aspek yaitu kinerja (Performance), informasi (Information), ekonomi (Economy), pengendalian (Control), efisiensi (Eficiency), pelayanan (Service).

Tahap pengembangan dalam pembuatan sistem penjualan berbasis web ini menggunakan model waterfall yang dimana dalam pengembangannya melalui tahapan-tahapan dibawah ini.

1. Analisis dan Definisi Kebutuhan

Tahap untuk menetapkan berbagai kebutuhan yang diperlukan dalam pelaksanaan pembuatan perangkat lunak, seperti menganalisis data yang diperlukan, tool apa saja yang akan digunakan, analisis kerja sistem, menganalisis aliran data yang akan berjalan pada sistem. Adapun beberapa cara yang dapat dilakukan untuk mengumpulkan data diantaranya : a. Observasi

Dilakukan dengan cara pengamatan secara langsung di dalam sistem yang sedang berjalan untuk dapat mengidentifikasi masalah dan kebutuhan sistem.

b. Wawancara

Wawancara dilakukan kepada pihakpihak yang terlibat di dalam sistem untuk membantu penulis menganalisis kekurangan ataupun kebutuhan yang ada di dalam sistem yang berjalan.

c. Studi Pustaka

Penulis mempelajari buku-buku ataupun artikel-artikel yang berkaitan dengan judul penelitian guna menambah wawasan penulis terhadap topik yang dibahas dan juga sebagai acuan dalam melakukan pengembangan dan implementasi sistem.

2. Perancangan Sistem dan Perangkat Lunak Merupakan tahap pembuatan desain sistem secara menyeluruh berdasarkan data kebutuhan atau persyaratan yang telah ditetapkan. Juga mengidentifikasi dan mendeskripsikan gambaran umum dari sistem perangkat lunak dan hubunganhubungannya.

3. Implementasi dan Pengujian Unit

Merupakan tahap implementasi dan pengujian terhadap perangkat lunak yang telah dibangun. Pengujian dilakukan sesuai dengan kerja program yang diinginkan, misalnya menguji penambahan data produk, sistem pencarian produk, dan lain-lain. Pengujian dilakukan untuk memastikan apakah unit-unit program yang dibuat sudah memenuhi spesifikasinya.

4. Integrasi dan Pengujian Sistem

Merupakan tahap dimana unit-unit program diintegrasikan dan diuji sebagai sebuah sistem secara lengkap. Pengujian dilakukan untuk memastikan apakah secara keseluruhan sistem sudah dapat berjalan sesuai dengan yang diinginkan atau direncanakan.

5. Operasi dan Pemeliharaan

Merupakan tahap akhir dalam pengembangan suatu sistem dimana sistem dipasang dan mulai digunakan. Tahap pemeliharaan melingkupi perbaikan dari kesalahan yang tidak ditemukan pada tahap perancangan, dan 
pengembangan sistem seperti penambahan fungsi baru.

\section{HASIL DAN PEMBAHASAN}

\section{Implementasi Sistem}

Implementasi sistem adalah tahap lanjutan dari tahap perancangan sistem, dimana sistem usulan yang dikembangkan telah siap untuk dioperasikan.

\section{Implementasi Database}

Implementasi database untuk sistem penjualan barang berbasis web yang menggunakan mysql. Berikut tampilan beberapa tabel dalam database yang digunakan :

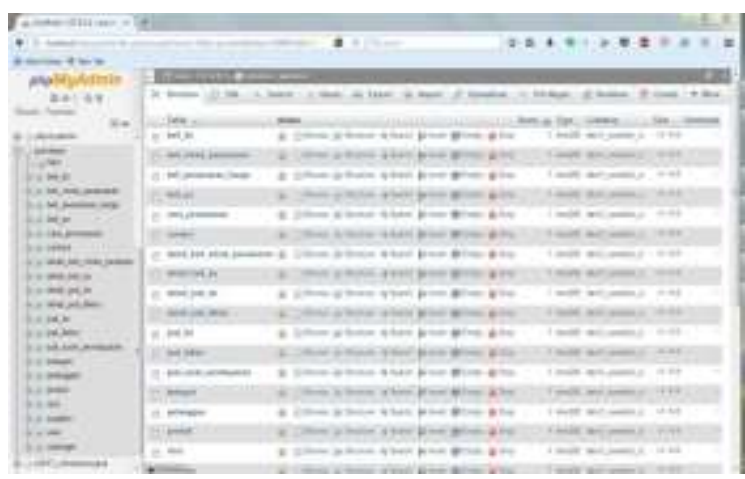

Gambar 1. Tampilan Database

\section{Implementasi Antarmuka}

Implementasi antarmuka menggambarkan tampilan-tampilan yang ada di dalam aplikasi yang digunakan :

1. Tampilan halaman awal

Ketika pihak pelanggan maupun pihak admin mengakses website, akan muncul halaman awal.

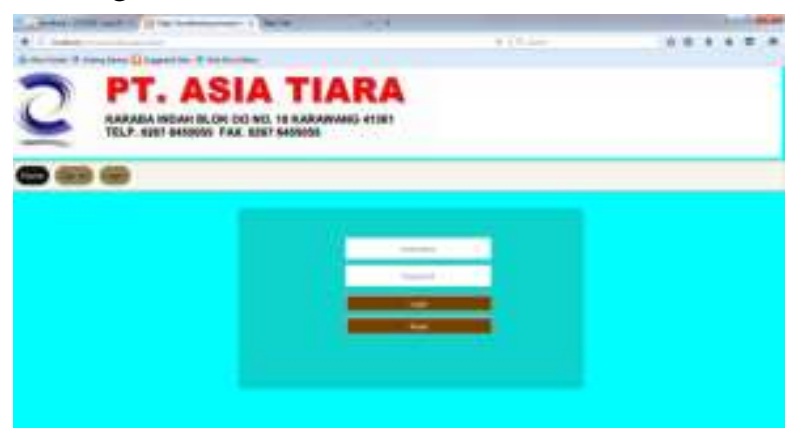

Gambar 2. Halaman Login

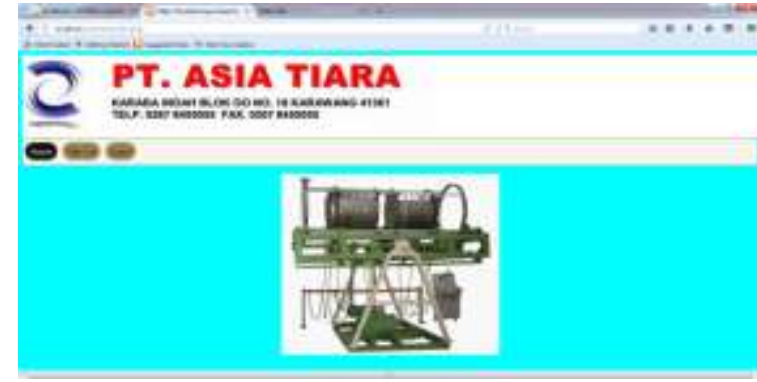

Gambar 3. Halaman Awal

\section{Halaman Sign Up}

Untuk dapat melakukan proses transaksi pelanggan harus terlebih dahulu memiliki akun untuk dapat login dan mengakses menu-menu untuk transaksi.

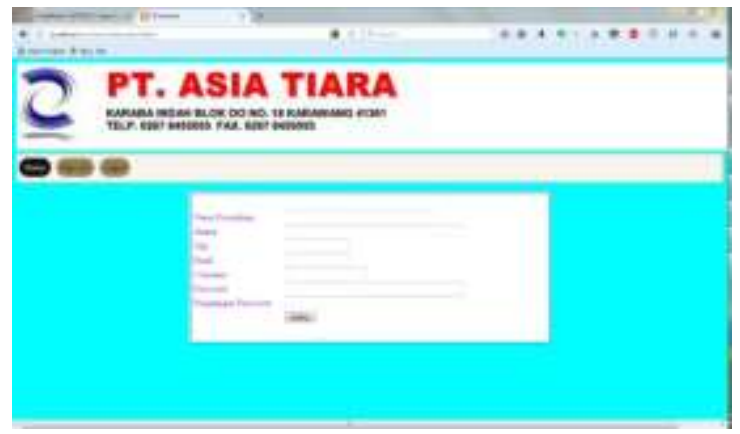

Gambar 4. Halaman Sign Up

3. Halaman Login

Untuk dapat mengakses menu lanjutan dalam sistem, baik pelanggan maupun admin harus terlebih dahulu login ke dalam sistem. Berikut adalah tampilan halaman login.

\section{Menu Contact}

Menu contact digunakan oleh pelanggan untuk mengunggah file permintaan penawaran harga.

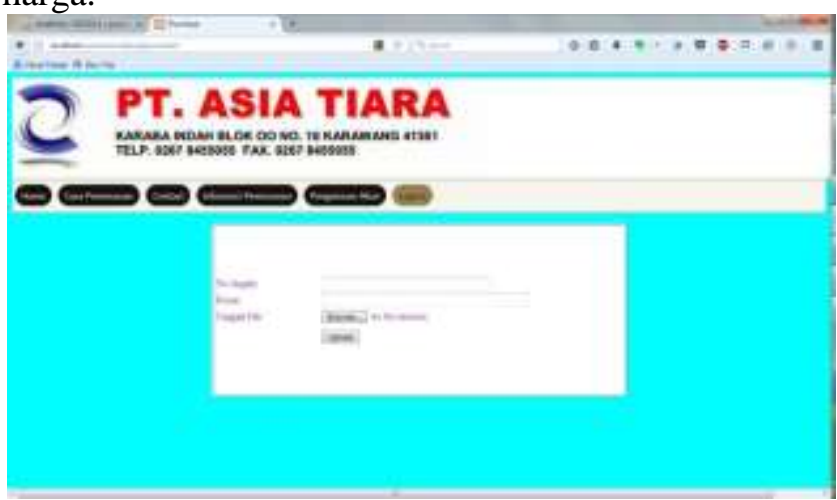

Gambar 5.Contact 
5. Menu Informasi Pemesanan

Di menu informasi pemesanan, pelanggan dapat melihat penawaran harga yang diberikan oleh perusahaan.

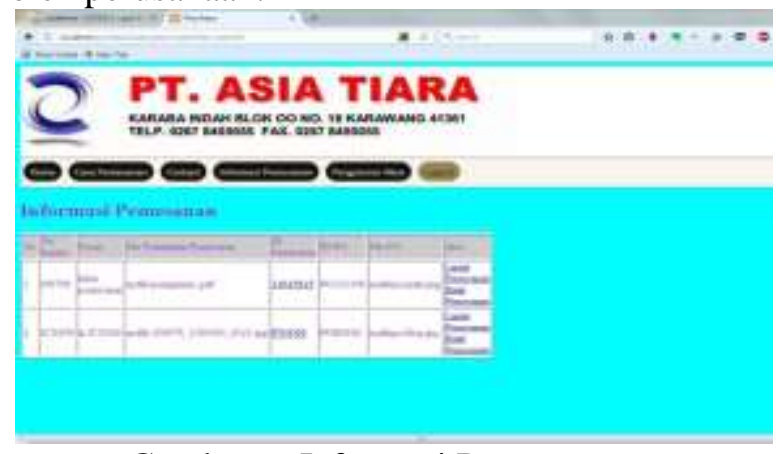

Gambar 6. Informasi Pemesanan

\section{Pengujian Sistem}

Pengujian merupakan bagian yang penting dalam siklus pembangunan perangkat lunak. Pengujian dilakukan untuk menjamin kualitas dan juga mengetahui kelemahan dari perangkat lunak. Tujuan dari pengujian adalah menjamin bahwa perangkat lunak yang dibangun sudah sesuai dengan keperluan sistem.

Tabel 1. Pengujian Menu

\begin{tabular}{|c|c|c|c|c|}
\hline Nama Deuguiazu & Masuka & 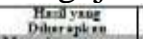 & Kofluara & 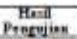 \\
\hline 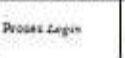 & 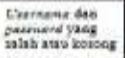 & 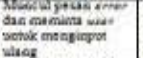 & 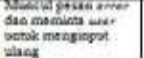 & ok \\
\hline Drosen Legen & 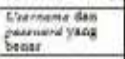 & 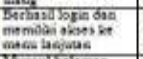 & 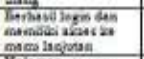 & ow \\
\hline 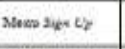 & $\begin{array}{l}\text { Nemader mems } \\
\text { Her w }\end{array}$ & 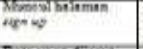 & 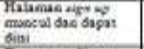 & ak \\
\hline 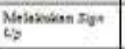 & 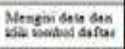 & 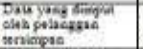 & 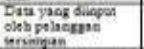 & $\alpha k$ \\
\hline 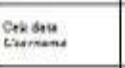 & 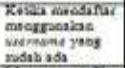 & 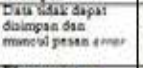 & 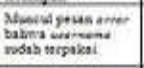 & ole \\
\hline Mons everiand & 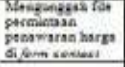 & 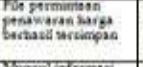 & 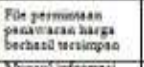 & os \\
\hline 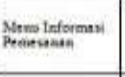 & 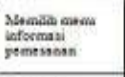 & 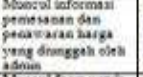 & 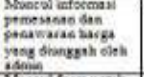 & ok \\
\hline 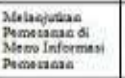 & 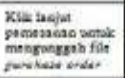 & 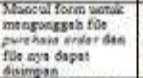 & 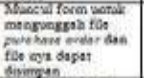 & ove \\
\hline Memo Tramibial & 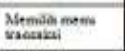 & 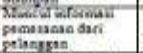 & 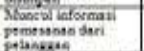 & ** \\
\hline 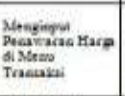 & 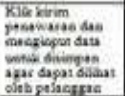 & 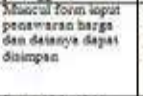 & 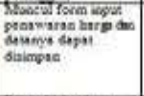 & * \\
\hline 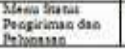 & 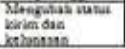 & 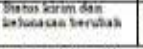 & 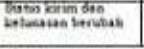 & ok: \\
\hline 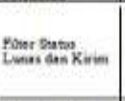 & 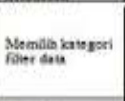 & 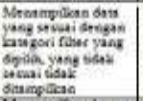 & 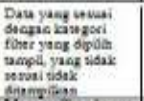 & o* \\
\hline 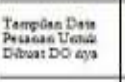 & 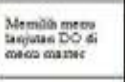 & 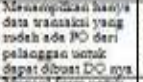 & 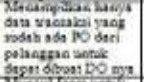 & $\omega$ \\
\hline Nentosatido & 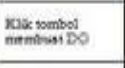 & 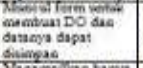 & 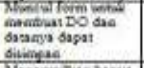 & $\Delta$ \\
\hline 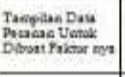 & 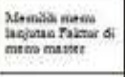 & 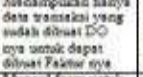 & 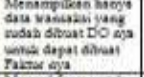 & o* \\
\hline Mrmbuan Priense & 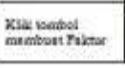 & 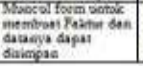 & 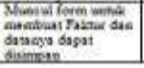 & o* \\
\hline
\end{tabular}

\section{KESIMPULAN DAN SARAN}

\section{Kesimpulan}

Berdasarkan analisis dan pembahasan yang telah diuraikan pada bab-bab sebelumnya, dapat diambil beberapa kesimpulan sebagai berikut :

1. Sistem penjualan berbasis web memudahkan pihak pelanggan dan pihak perusahaan untuk melakukan transaksi, karena pelanggan dan perusahaan dapat berinteraksi dalam satu sistem yang menghubungkan satu dengan yang lain.

2. Tersedianya menu pengolahan data transaksi dalam sistem memudahkan karyawan untuk mengolah data tanpa harus membuka aplikasi lain.

3. Penggunaan sebuah basis data untuk menyimpan data-data transaksi memudahkan proses monitoring transaksi.

\section{Saran}

Terdapat beberapa hal yang belum digali lebih mendalam dalam perancangan sistem ini, sehingga untuk ke depannya masih dapat dikembangkan dan diperbaiki, antara lain :

1. Perancangan tampilan yang masih sederhana untuk dapat dibuat lebih menarik.

2. Sistem harus dikembangkan lebih lanjut untuk meminimalisir terjadinya kesalahan, yaitu dengan memaksimalkan fungsi message box untuk memberi peringatan apabila terjadi kesalahan pada saat input.

\section{DAFTAR PUSTAKA}

Ahmadi dan Hermawan. (2013). E-Business \& E-Commerce. Yogyakarta: Andi.

Amir, Taufiq, M. (2013). Inovasi Pendidikan Melalui Problem Based Learning. Jakarta

: Kencana Prenada Media Group.

Anhar. (2010). Panduan Menguasai PHP dan MySQL Secara Otodidak. Jakarta : Media Kita.

Arief, M Rudianto. (2011). Pemrograman Web Dinamis menggunakan PHP dan MySQL. Yogyakarta : Andi.

Connolly, Thomas and Begg, Carolyn. (2010). Database Systems: A Practical Approach 
to Design, Implementation, and Management, Fifth Edition. Boston : Pearson Education.

Darmawan, Deni. (2013). Metode penelitian kuantitatif. Bandung : PT Remaja Rosdakarya

Haughee. Eric. (2013). Instant Sublime Text Starter. Birmingham: Packt Publishing Ltd

Indrajani. (2011). Perancangan Basis Data dalam All in 1. Jakarta : PT. Elex Media Komputindo.

Mardi. (2011). Sistem Informasi Akuntasi. Jakarta : anggota IKAPI, Ghalia

Mulyadi. (2013). Sistem Akuntansi. Jakarta: Salemba Empat.

Murya, Yosef, dan Rizki Hesananda. (2014). Project PHP 15 JUTA: Membuat toko eBook online dengan bootstrap twitter 3 \& PHP MySQL. Jakarta : Jasakom.

Nanehkaran, Yaser A. (2013). An Introduction to Electronic Commerce. International Journal of Scientific and Technology Research, Vol. 2, Issue 4. 190-193.

Nidhra, Srinivas dan Dondeti, Jagruthi . (2012). Black Box And White Box Testing Techniques -A Literature Review, International Journal of Embedded Systems and Applications (IJESA) Vol.2, No.2, 8-9

Nugroho, Adi. (2010). "rekayasa perangkat lunak menggunakan UML dan Java". Yogyakarta : Andi Offset.

Puspitawati, Lilis., Sri Dewi Anggadini. (2011). Sistem Informasi Akuntansi. Yogyakarta: Graha Ilmu.

Quadri, S.M.K, \& Farooq, Sheikh Umar. (2010). Soft ware Testing -Goals, Principles, and Limitations. International Journal of Computer Applications, 6(9), 1

Ragil, Wukil. (2010). Pedoman Sosialisasi Prosedur Operasi Standar. Jakarta : PT. Prestasi Pustakaraya.
Riyanto. (2011). Sistem Informasi Penjualan dengan PHP dan MySQL. Yogyakarta : Gava Media

Rizky, Soetam. (2011). Konsep Dasar Rekayasa Perangkat Lunak. Jakarta : PT. Prestasi Pustakaraya

Saputra, Agus, Ridho Taufiq Subagio dan Saluky. (2012). Membangun Aplikasi ELibrary Untuk Panduan Skripsi. Jakarta : PT. Elex Media Komputindo

Sarwono, Jonathan dan K Prihartono, A.H. (2012). Perdagangan Online : Cara Bisnis di Internet. Jakarta: PT. Elex Media Komputindo.

Sommerville, Ian. (2011). Software-Engineering 9th edition. Addison-Wesley : Pearson.

Subhan, M. (2012). Analisa Perancangan Sistem. Jakarta : Lentera Ilmu Cendekia.

Sugianto. (2013). Metode Penelitian Manajemen. Bandung : Alfabeta.

Sukamto, R. A., dan Shalahudin, M. (2014). Rekayasa Perangkat Lunak Terstruktur Dan Berorientasi Objek. Bandung: Informatika.

Susanto, Azhar. (2013). Sistem Informasi Akuntansi. Bandung: Lingga Jaya.

Sutabri, Tata. (2012).Analisis Sistem Informasi. Yogyakarta : Andi.

Sutabri, Tata. (2012). Konsep Sistem Informasi. Yogyakarta : Andi.

Sutanta, Edhy. (2011). Basis Data Dalam Tinjauan Konseptual. Yogyakarta : Andi.

Widodo, Prabowo Pudjo, Herlawati. (2011). Menggunakan UML. Bandung : Informatika.

Wong, Jony. (2010). Internet Marketing for Beginners. Jakarta : PT Elex Media Komputindo.

Yeni Kustiyahningsih, Devie Rosa Anamisa. (2011). Pemograman Basis Data Berbasis Web Menggunakan PHP \& MySQL. Yogyakarta : Graha Ilmu. 